\title{
A Cross Sectional Observational Study on Prescribing Patterns of Drugs in Chronic Kidney Disease Patients in a Tertiary Care Teaching Hospital
}

\section{Roja Rani K*, Susmitha Bhaskar Yerramasetty and Prasanth Munaswamy}

Pharm D, Department of Pharmacy Practice, Sri Padmavathi School of Pharmacy,

Tirupathi, Andhra Pradesh, India

*Corresponding Author: Roja Rani K, Pharm D, Department of Pharmacy Practice, Sri Padmavathi School of Pharmacy, Tirupathi, Andhra Pradesh, India.
Received: September 02, 2020

Published: October 08, 2020

(C) All rights are reserved by Roja Rani K., et al.

\section{Abstract}

The prevalence of Chronic Kidney Disease are enormously increasingly world wide due to gradual rise in hypertension, diabetes, cardiovascular diseases. As kidney is a major eliminating organ, its function decreases in CKD resulting in accumulation of drugs which leads to toxic effects. Use of poly pharmacy in co- morbid conditions results in drug - drug interactions and adverse effects which may cause serious and long term illness and decrease quality of life of patient. The aim is to assess the prescribing patterns of drugs in chronic kidney patients in a tertiary care teaching hospital. Objectives are to assess the prescribing drug doses in CKD patients. To identify the risk factors in CKD. To predict the GFR by using Modified diet in renal failure formulae. To evaluate the comorbidities involved in CKD. To determine the number of drugs prescribed belong WHO essential list. To analyse the drug interactions involved in prescriptions. To assess the prescribing patterns of prescribers in CKD patients. To determine the usage of drugs by using WHO prescribing indicators. A prospective observational study carried out in Sri Venkateswara Ramnarayan Ruia Government General Hospital (SVRRGGH) during December 2016 to March 2017 (6 months). A total of 125 patients diagnosed with CKD are included in study. Patients who are not willing, below 18 years, special population including pregnant, lactating women were excluded from study. Predesigned proforma was used to collect data. Total of 125 patients were included in study, men constituted 68\% of total population. Most effected age group was 51-60 years. Hypertension was major risk factor 48.20\% observed in study population. Most of patients are in stage 4, 35.20\%. 1163 drugs were prescribed to 125 patients. Percentage of drugs prescribed from WHO EDL was $62.90 \%$. Prevalence of polypharmacy was very high in patients with CKD. Medication prescribing patterns suggest a high number of medications used in CKD patients with increased possibility of drug interactions. Continuous medical education of physicians and collaboration with clinical pharmacist is an important issue for quality improvement regarding renally impaired patients.

Keywords: Chronic Kidney Disease; WHO; Drugs

\section{Introduction}

Prescription pattern studies are drug utilisation studies which explains about prescribing, dispensing and administering of drugs. They explain about drug use, quality of drugs, trends and compliance with standard treatment guidelines, usage of drugs from essential medicine list and use of generic drugs [1]. The main aim of Prescription pattern studies is to promote the rational use of drugs in a public. According to WHO more than half of the medicines are prescribed and dispensed inappropriately. Chronic Kidney Disease is a world wide public health problem with an increasing incidence, prevalence, poor outcomes and high cost. Outcomes of CKD include kidney failure, complications of decreased kidney function and cardiovascular disease. Chronic kidney disease decreases kidney function, resulting in decrease in elimination of drugs which leads to 
accumulation of drugs and precipitation of adverse drug reaction. Chronic kidney disease affects the elimination of renally excreted drugs and other pharmacokinetic processes involved in drug disposition (e.g. absorption, drug distribution, metabolism). In renal ill patients dosing error are common and can lead to adverse effects and poor outcomes. The Kidney Disease Outcomes Quality Initiative (K/DOQI) of the National Kidney Foundation (NKF) defines CKD as either kidney damage or a decreased glomerular filtration rate of less than $60 \mathrm{~mL} / \mathrm{min} / 1.73 \mathrm{~m}^{2}$ for 3 or more months [2].

\section{Aim of the Study}

To assess prescribing patterns of drugs in chronic kidney disease patients in a tertiary care teaching hospital.

\section{Objectives of the Study}

- To assess the prescribing drug doses in chronic kidney disease patients.

- To identify the risk factors associated in CKD patient.

- To evaluate the comorbidities involved in chronic kidney disease.

- To determine the number of drugs prescribed belong WHO essential list.

- To analyze drug interactions involved in prescription.

- To assess the prescribing patterns of prescribers in CKD patients.

- To determine the prescribing indicators involved according WHO prescribing indicators.

\section{Methodology}

Study design: Cross sectional observational study.

Study place: Sri Venkateswara Ramnarayan Ruia Government General Hospital. (SVRRGGH).

Study duration: 6 months.

Study population: 125 prescriptions.

Study site: Department of General Medicine.

Inclusion criteria

- All patients with diagnosis of CKD in general medicine department both male and female medical wards.

\section{Exclusion criteria}

- Patients below 18 years.

- Patients who were not willing.

- Special population including pregnant women and lactating women.

\section{Data collection}

A designed proforma and informed consent form was used for collection of data. The proforma contain patient demographics, diagnosis, admission complaints, past medical history, past medication history, family and surgical history, laboratory investigation reports and drugs prescribed. Evaluation proforma was used to evaluate data from proforma. Evaluation proforma contain infor- mation on co-morbidities, risk factors in CKD patients, estimation of GFR, CKD stage, drug interactions.

\section{Results}

Gender wise distribution of study population

\begin{tabular}{|l|c|c|}
\hline Sex & No. of patients $(\mathbf{n}=\mathbf{1 2 5})$ & Percentage \\
\hline Male & 85 & $68 \%$ \\
\hline Female & 40 & $32 \%$ \\
\hline
\end{tabular}

Table 1

Age wise distribution of study population

\begin{tabular}{|l|c|c|c|c|}
\hline Age & $\begin{array}{c}\text { Female } \\
(\mathbf{n = 3 9 )}\end{array}$ & $\begin{array}{c}\text { Male } \\
(\mathbf{n = 8 6})\end{array}$ & $\begin{array}{c}\text { Total } \\
(\mathbf{n = 1 2 5})\end{array}$ & Percentage \\
\hline $20-30$ & 1 & 3 & 4 & $3.20 \%$ \\
\hline $31-40$ & 7 & 4 & 11 & $8.80 \%$ \\
\hline $41-50$ & 8 & 18 & 26 & $20.80 \%$ \\
\hline $51-60$ & 12 & 25 & 37 & $29.60 \%$ \\
\hline $61-70$ & 4 & 27 & 31 & $24.80 \%$ \\
\hline $71-80$ & 7 & 8 & 15 & $12 \%$ \\
\hline $81-90$ & 0 & 1 & 1 & $0.80 \%$ \\
\hline
\end{tabular}

Table 2

Chronic kidney disease with comorbidities

\begin{tabular}{|l|c|c|}
\hline Comorbidities & $\begin{array}{c}\text { No. of patients } \\
\text { (n = 259) }\end{array}$ & Percentage \\
\hline Hypertension & 67 & $25.80 \%$ \\
\hline Diabetes mellitus & 41 & $15.80 \%$ \\
\hline Anaemia & 22 & $8.49 \%$ \\
\hline congestive cardiac failure & 19 & $7.30 \%$ \\
\hline Acute kidney injury & 10 & $3.86 \%$ \\
\hline coronary artery disease & 9 & $3.47 \%$ \\
\hline Ischemic Cardiomyopathy & 7 & $2.70 \%$ \\
\hline Cerebrovascular accident & 7 & $2.70 \%$ \\
\hline Gastro enteritis & 6 & $2.31 \%$ \\
\hline $\begin{array}{l}\text { Lower respiratory tract infec- } \\
\text { tions }\end{array}$ & 5 & $1.93 \%$ \\
\hline Pulmonary tuberculosis & 5 & $1.93 \%$ \\
\hline $\begin{array}{l}\text { Chronic obstructive pulmo- } \\
\text { nary disease }\end{array}$ & 5 & $1.93 \%$ \\
\hline Acid peptic disease & 4 & $1.54 \%$ \\
\hline Hepatitis B virus & 4 & $1.54 \%$ \\
\hline Stroke & 4 & $1.54 \%$ \\
\hline Diabetic neuropathy & 4 & $1.54 \%$ \\
\hline Chronic liver disease & 3 & $1.15 \%$ \\
\hline $\begin{array}{l}\text { Decompensated chronic liver } \\
\text { disease }\end{array}$ & 3 & $1.15 \%$ \\
\hline Dilated cardiac myopathy & 3 & $1.15 \%$ \\
\hline Pulmonaryoedema & 3 & $1.15 \%$ \\
\hline Filariasis & 2 & $0.77 \%$ \\
\hline Left ventricular disease & 20 & $0.77 \%$ \\
\hline Diabetic foot & & $0.77 \%$ \\
\hline Emphysema & $0.77 \%$ \\
\hline OTHERS & $7.77 \%$ \\
\hline
\end{tabular}

Table 3

Citation: Roja Rani K., et al. "A Cross Sectional Observational Study on Prescribing Patterns of Drugs in Chronic Kidney Disease Patients in a Tertiary Care Teaching Hospital". Acta Scientific Pharmaceutical Sciences 4.11 (2020): 30-37. 
A Cross Sectional Observational Study on Prescribing Patterns of Drugs in Chronic Kidney Disease Patients in a Tertiary Care Teaching Hospital

Risk factors in study population

\begin{tabular}{|l|c|c|}
\hline Risk factor & No. of patients (n = 147) & Percentage \\
\hline Hypertension & 71 & $48.20 \%$ \\
\hline Diabetes mellitus & 32 & $21.70 \%$ \\
\hline Acute kidney injury & 6 & $4 \%$ \\
\hline Others & 38 & $25.80 \%$ \\
\hline
\end{tabular}

Table 4

Stages of CKD in study population

\begin{tabular}{|l|c|c|}
\hline CKD Stage & No. of patients (n = 125) & Percentage \\
\hline Stage- 1 & 5 & $4 \%$ \\
\hline Stage- 2 & 9 & $7.20 \%$ \\
\hline Stage-3a & 13 & $10.40 \%$ \\
\hline Stage-3b & 7 & $5.60 \%$ \\
\hline Stage- 4 & 44 & $35.20 \%$ \\
\hline Stage-5 & 43 & $34.40 \%$ \\
\hline None & 4 & $3.20 \%$ \\
\hline
\end{tabular}

Table 5
Hemoglobin levels in female study population

\begin{tabular}{|l|c|c|}
\hline Hemoglobin $(\mathbf{g} / \mathbf{d l})$ & Female $(\mathbf{n}=\mathbf{4 0})$ & Percentage \\
\hline$>11$ & 1 & $2 \%$ \\
\hline$<11$ & 39 & $98 \%$ \\
\hline
\end{tabular}

Table 6

Hemoglobin levels in male study population

\begin{tabular}{|l|c|c|}
\hline Hemoglobin $(\mathrm{g} / \mathrm{dl})$ & Male $(\mathbf{n}=\mathbf{8 5})$ & Percentage \\
\hline$>13$ & 6 & $7 \%$ \\
\hline$<13$ & 79 & $92.85 \%$ \\
\hline
\end{tabular}

Table 7

Distribution of erythropoietin in study population

\begin{tabular}{|l|c|c|}
\hline Gender & \multicolumn{2}{|c|}{ Erythropoietin (n = 125) } \\
\hline & Yes & No \\
\hline Male & 16 & 69 \\
\hline Female & 9 & 31 \\
\hline Total & 25 & 100 \\
\hline Percentage & $20 \%$ & $80 \%$ \\
\hline
\end{tabular}

Table 8

Pattern of antihypertensive therapy in CKD patients

\begin{tabular}{|l|c|c|}
\hline \multicolumn{3}{|c|}{ Anti hypertensive drugs } \\
\hline Drugs & Number of patients & Percentage \\
\hline Furosemide & Monotherapy (29.91\%) & \\
\hline Amlodipine & 30 & $85.70 \%$ \\
\hline Enalapril & 4 & $11.43 \%$ \\
\hline Total & 1 & $2.85 \%$ \\
\hline & 35 & $100 \%$ \\
\hline Furosemide+amlodipine & Two drug therapy & \\
\hline Furosemide+spironolactone & $29.91 \%)$ & $74.28 \%$ \\
\hline Furosemide+metolazone & 26 & $17.14 \%$ \\
\hline Amlodipine+prazosin & 2 & $5.71 \%$ \\
\hline Telmisartan+atenolol & 1 & $2.85 \%$ \\
\hline Total & 35 & $2.85 \%$ \\
\hline & 2 & $100 \%$ \\
\hline Furosemide+amlodipine+prazosin & 11 & \\
\hline Furosemide+amlodipine+metolazone & 5 & $30.50 \%$ \\
\hline Furosemide+amlodipine+ & 2 & $13.80 \%$ \\
\hline Spironolactone & & $5.50 \%$ \\
\hline Furosemide+amlodipine+clonidine & $20.7 \%)$ & \\
\hline
\end{tabular}

Citation: Roja Rani K., et al. "A Cross Sectional Observational Study on Prescribing Patterns of Drugs in Chronic Kidney Disease Patients in a Tertiary Care Teaching Hospital". Acta Scientific Pharmaceutical Sciences 4.11 (2020): 30-37. 
A Cross Sectional Observational Study on Prescribing Patterns of Drugs in Chronic Kidney Disease Patients in a Tertiary Care Teaching Hospital

\begin{tabular}{|c|c|c|}
\hline Furosemide+amlodipine+atenolol & 2 & $5.50 \%$ \\
\hline Furosemide+amlodipine+enalapril & 2 & $5.50 \%$ \\
\hline $\begin{array}{l}\text { Furosemide+metoprolol+ } \\
\text { Spironolactone }\end{array}$ & 2 & $5.50 \%$ \\
\hline $\begin{array}{l}\text { Furosemide+spironolactone+ } \\
\text { Propranolol }\end{array}$ & 2 & $5.50 \%$ \\
\hline $\begin{array}{l}\text { Furosemide+spironolactone+ } \\
\text { Enalapril }\end{array}$ & 2 & $5.50 \%$ \\
\hline Furosemide+metolazone+prazosin & 3 & $8.30 \%$ \\
\hline $\begin{array}{l}\text { Furosemide+enalapril+ } \\
\text { Metoprolol }\end{array}$ & 1 & $2.70 \%$ \\
\hline $\begin{array}{l}\text { Furosemide+amlodipine+ } \\
\text { Propranolol }\end{array}$ & 1 & $2.70 \%$ \\
\hline $\begin{array}{l}\text { Metoprolol+enalapril+ } \\
\text { Spironolactone }\end{array}$ & 1 & $2.70 \%$ \\
\hline Total & $\begin{array}{c}36 \\
\text { Four drug therapy } \\
(7.69 \%)\end{array}$ & $100 \%$ \\
\hline $\begin{array}{l}\text { Furosemide+amlodipine+ } \\
\text { Metolazone+metoprolol }\end{array}$ & 2 & $22.20 \%$ \\
\hline $\begin{array}{l}\text { Furosemide+amlodipine+ } \\
\text { Spironolactone+atenolol }\end{array}$ & 1 & $11.10 \%$ \\
\hline $\begin{array}{l}\text { Furosemide+amlodipine+ } \\
\text { Labetalol+enalapril }\end{array}$ & 1 & $11.10 \%$ \\
\hline $\begin{array}{l}\text { Furosemide+amlodipine+prazosin+ } \\
\text { Enalapril }\end{array}$ & 1 & $11.10 \%$ \\
\hline $\begin{array}{l}\text { Furosemide+prazosin+metolazone+ } \\
\text { nifedipine }\end{array}$ & 1 & $11.10 \%$ \\
\hline $\begin{array}{l}\text { Furosemide+amlodipine+ } \\
\text { Spironolactone+enalapril }\end{array}$ & 1 & $11.10 \%$ \\
\hline $\begin{array}{l}\text { Furosemide+spironolactone+ } \\
\text { Enalapril+metoprolol }\end{array}$ & 1 & $11.10 \%$ \\
\hline $\begin{array}{l}\text { Frosemide+prazosine+amlodipine+ } \\
\text { Metolazone }\end{array}$ & 1 & $11.10 \%$ \\
\hline \multirow[t]{2}{*}{ Total } & 9 & $100 \%$ \\
\hline & Five drug therapy $(1.7 \%)$ & \\
\hline $\begin{array}{l}\text { Furosemide+amlodipine+enalapril+ } \\
\text { Metolazone+prazosin }\end{array}$ & 2 & \\
\hline
\end{tabular}

Table 9

Citation: Roja Rani K., et al. "A Cross Sectional Observational Study on Prescribing Patterns of Drugs in Chronic Kidney Disease Patients in a Tertiary Care Teaching Hospital". Acta Scientific Pharmaceutical Sciences 4.11 (2020): 30-37. 
A Cross Sectional Observational Study on Prescribing Patterns of Drugs in Chronic Kidney Disease Patients in a Tertiary Care Teaching Hospital

Overall patterns of antihypertensive drugs prescribed in CKD

patients

\begin{tabular}{|c|c|c|}
\hline Drug group & Frequency $(n=235)$ & Percentage \\
\hline \multicolumn{3}{|l|}{ Diuretics } \\
\hline Spironolactone & 18 & $7.65 \%$ \\
\hline Metolazone & 11 & $4.68 \%$ \\
\hline Furosemide & 97 & $41.27 \%$ \\
\hline \multicolumn{3}{|l|}{ Ace inhibitors } \\
\hline Enalapril & 13 & $5.53 \%$ \\
\hline \multicolumn{3}{|l|}{ CCBS } \\
\hline Amlodipine & 58 & $24.68 \%$ \\
\hline Nifedipine & 1 & $0.42 \%$ \\
\hline \multicolumn{3}{|l|}{ Alfa blokers } \\
\hline Prazosin & 14 & $5.95 \%$ \\
\hline \multicolumn{3}{|l|}{ Beta blokers } \\
\hline Propranolol & 3 & $1.27 \%$ \\
\hline Metoprolol & 7 & $2.97 \%$ \\
\hline Atenolol & 4 & $1.70 \%$ \\
\hline Labetalol & 1 & $0.42 \%$ \\
\hline \multicolumn{3}{|l|}{ ARBS } \\
\hline Telmisartan & 1 & $0.42 \%$ \\
\hline \multicolumn{3}{|l|}{ Alpha agonist } \\
\hline Clonidine & 3 & $1.27 \%$ \\
\hline
\end{tabular}

Table 10

Pattern of antidiabetics in CKD patients

\begin{tabular}{|l|c|c|}
\hline Antidiabetic Drugs & No of Drugs (N = 51) & Percentage \\
\hline Oral Hypoglycemic Agents & & \\
\hline One Drug Therapy & Total 4 (7.84\%) & $100 \%$ \\
\hline Metformin & 2 & $50 \%$ \\
\hline Glimepride & 1 & $25 \%$ \\
\hline Glibenclamide & 1 & $25 \%$ \\
\hline Total & 4 & \\
\hline Two Drug Therapy & Total 5 & \\
\hline Metformin+Glimepride & $5(9.8 \%)$ & \\
\hline Insulin Therapy & & $100 \%$ \\
\hline Single Insulin Therapy & Total 34 (66.6\%) & $64.70 \%$ \\
\hline Plain insulin & 22 & $35.29 \%$ \\
\hline NPH insulin & 12 & \\
\hline Total & 34 & \\
\hline Two Insulin Therapy & Total 3 & \\
\hline Plain insulin+NPH insulin & $3(5.8 \%)$ & $60 \%$ \\
\hline Oral Hypoglycemic Agents+Insulin Therapy & Total 5 (9.8\%) & $40 \%$ \\
\hline (Metformin+Glimepride)+NPH insulin & 3 & \\
\hline (Metformin+Glimepride)+Plain insulin & 2 & \\
\hline
\end{tabular}

Table 11

Citation: Roja Rani K., et al. "A Cross Sectional Observational Study on Prescribing Patterns of Drugs in Chronic Kidney Disease Patients in a Tertiary Care Teaching Hospital". Acta Scientific Pharmaceutical Sciences 4.11 (2020): 30-37. 
A Cross Sectional Observational Study on Prescribing Patterns of Drugs in Chronic Kidney Disease Patients in a Tertiary Care Teaching Hospital

Distribution of prescribed drugs based on category

\begin{tabular}{|l|c|c|}
\hline Drug category & $\begin{array}{c}\text { No. of drugs } \\
\text { (n = 1163) }\end{array}$ & Percentage \\
\hline Antihypertensives & 235 & $20.20 \%$ \\
\hline Vitamins and minerals & 188 & $16.10 \%$ \\
\hline Antibiotics & 136 & $11.69 \%$ \\
\hline Antiulcer drugs & 114 & $9.80 \%$ \\
\hline Anaemic Drug & 83 & $7.10 \%$ \\
\hline Antiplatelets & 53 & $4.50 \%$ \\
\hline Antidiabetics & 51 & $4.48 \%$ \\
\hline Bronchodilators & 44 & $3.78 \%$ \\
\hline Lipid lowering agents & 40 & $3.43 \%$ \\
\hline Alkalisers & 22 & $1.89 \%$ \\
\hline Laxatives & 12 & $1.03 \%$ \\
\hline Cardiac glycosides & 12 & $1.03 \%$ \\
\hline Antitubercular therapy & 12 & $1.03 \%$ \\
\hline Corticosteroids & 11 & $0.94 \%$ \\
\hline Analgesics & 7 & $0.60 \%$ \\
\hline Nitrates & 6 & $0.51 \%$ \\
\hline Anticoagulants & 5 & $0.42 \%$ \\
\hline Antifungals & 2 & $0.73 \%$ \\
\hline Thyroid drugs & 1 & $0.08 \%$ \\
\hline Others & 129 & $11.09 \%$ \\
\hline
\end{tabular}

Table 12

Possible drug - drug interactions in study population

\begin{tabular}{|l|c|c|}
\hline Severity & No. observed $(\mathbf{n}=\mathbf{2 8 2})$ & Percentage \\
\hline Major & 138 & $48.90 \%$ \\
\hline Moderate & 117 & $41.40 \%$ \\
\hline Minor & 27 & $9.57 \%$ \\
\hline
\end{tabular}

\section{Table 13}

Prescribing indicators

\begin{tabular}{|l|c|}
\hline Indicators & Value \\
\hline Total number of prescriptions & 125 \\
\hline Total number of drugs prescribed & 1163 \\
\hline $\begin{array}{l}\text { Average number of drugs per } \\
\text { prescription }\end{array}$ & $9.3(1.6-1.8)$ \\
\hline $\begin{array}{l}\text { Percentage of drugs prescribed by } \\
\text { generic name }\end{array}$ & $52.27 \%(100 \%)$ \\
\hline $\begin{array}{l}\text { Percentage of prescriptions with } \\
\text { an injections prescribed }\end{array}$ & $95.20 \%(13.4-24.1 \%)$ \\
\hline $\begin{array}{l}\text { Percentage of prescriptions with } \\
\text { an antibiotics prescribed }\end{array}$ & $47.72 \%(13.4-24.1 \%)$ \\
\hline $\begin{array}{l}\text { Percentage of drugs prescribed } \\
\text { from WHO EDL 2015 }\end{array}$ & $62.90 \%(100 \%)$ \\
\hline
\end{tabular}

Table 14

\section{Discussion}

The prevalence of CKD cases are enormously increasingly world wide due to gradual rise in hypertension, diabetes, cardiovascular diseases and also inappropriate drug use and polypharmacy make people prone to drug induced renal disease in India. Most of drugs are extensively excreted by kidneys, in renal failure condition the drugs are accumulated and causes toxic or adverse effects.

The total of 125 patients were included in our study. Among total study population 85 patients were male and 40 patients are female. This explains that majority of a males population over females. This may be due to various risk factors like smoking, consumption is commonly high in men compared with women. These findings are similar to that of Tamilselvan T, Veerapandiyan AK., et al. study [3]

In the study, more number of patients are seen between age of 51 - 60 years ( 37 patients, $29.60 \%$ ), followed by 61 - 70 years (31 patients, $24.80 \%$ ). Age may be also one of risk factor for development of CKD, which is similar to Tamilselvan T, Veerapandiyan AK., et al. study [3].

The kidney plays a major role in the control of blood pressure by regulating sodium retention, extracellular fluid volume, and the renin-angiotensin system. Alteration in these mechanisms leads to hypertension in CKD. Hypertension $(67,25.80 \%)$ was the major co-morbidity in study population, followed by diabetes mellitus $(41,15.80 \%)$, followed by anaemia $(22,8.49 \%)$. Most of the patients were are to be having more than one co-morbidity.

In present study major risk factor found to be hypertension (71,48.20\%), followed by diabetes mellitus $(32,21.70 \%)$, followed by acute kidney injury $(6,4 \%)$. A patient may have more than one risk factor.

The study population with stage- $4(44,35.20 \%)$ were higher followed by Stage- 5 (43,34.40\%). These findings reveals that most of study population are with end stage renal disease.

Most of female patients are anaemic with haemoglobin less are than $11 \mathrm{~g} / \mathrm{dl}(39,98 \%)$ out of 40 female study population. In total of 85 male patients 79 were anaemic with haemoglobin less than $13 \mathrm{~g} / \mathrm{dl}(79,92.85 \%)$ out of 85 male study population. According to National kidney foundation females with haemoglobin less than 12 $\mathrm{g} / \mathrm{dl}$ and males with haemoglobin less are than $13 \mathrm{~g} / \mathrm{dl}$ are anaemic. The occurrence of anaemia in CKD patients is due to reduced production of erythropoietin in CKD patients. Erythropoietin is produced by kidneys which is one of its function.

Out of 125 study population, only $(25,20 \%)$ received erythropoietin even though majority are anaemic. Most of patients in government hospital are unable to get erythropoietin. 
Multiple drug therapy was usually followed by CKD patients due to their comorbid conditions such as hypertension, diabetes, cardiovascular disorders, phosphate retention, anaemia, dyslipidaemia, thyroid disorders, mineral imbalance etc. Hence along with antihypertensive and antidiabetic drugs the patients have to take other drugs based their comorbidity such as phosphate binders, vitamins, mineral supplements, antiplatelets etc.

Antihypertensives are given to reduce elevated blood pressure, to reduce cardiovascular diseases and reduce progression of Chronic kidney disease. This study shows that 35(29.91\%) received monotherapy of antihypertensives, 35(29.91\%) received two drug therapy, 36(30.7\%) received three drug therapy, $9(7.69 \%)$ received four drug therapy and $2(1.7 \%)$ received five drug therapy. Furosemide was most commonly prescribed drug in both in mono and combination drug therapy. The reported mono and combination use of Furosemide was 97(41.27\%). Majority antihypertentives were diuretics (216) followed by CCBs (59) and ACEI. Were as in Elahe Elhami and Kiran Nagaraju study [4] mostly prescribed drugs are ACEI followed by Diuretics and followed by CCBs. In Alwyn P Saju, Ankur C Edakkarayil., et al. study [5] CCBs are majorly prescribed drugs followed by Diuretics. ACEI and ARBs are first line choice of drugs in hypertension and with or with out diabetes according to JNC8 [6]. But in our hospital ACEI are less preferred drugs than others because its risk of hyperkalaemia and decreased GFR in patients and also need dose adjustments, as the patients are already renal impaired.

In this study majorly prescribed therapy was three drug therapy $30.7 \%$, followed by two drug and monotherapy (29.91\%). Furosemide+Amlodipine+Prazosin was mostly prescribed in three drug therapy 11 (30.50\%). In two drug therapy Furosemide+Amlodipine was majorly prescribed drugs 26 (74.28\%). In Elahe Elhami and Kiran Nagaraju study [4] mostly prescribed combinations were 30 (50\%) Hydrochlorothiazide + Enalapril, follow by Torsemide + enalapril15 (25\%) were the most commonly prescribed two-drug combination therapy in patients, Hydrochlorothiazide + Enalapril + Verapamil15 (62.50\%), follow by Furosemide+ Metoprolol + Prazosin (25\%) were the most commonly prescribed three-drug combination therapy in patients.

A total of 51 antidiabetic drugs were prescribed in 125 patients. The mostly prescribed antidiabetic drugs are Insulin therapy 34 (66.6\%) followed by two drug oral hypoglycaemic agents and combination of Oral hypoglycemicagents+insulin therapy 5 (9.8\%), fol- lowed by one drug therapy of oral hypoglycaemic agents 4 (7.84). In mono drug therapy of oral hypoglycemics metformin was mostly prescribed. According to National kidney foundation Metformin is contraindicated in male patients with a serum creatinine $>1.5 \mathrm{mg} /$ $\mathrm{dl}$ and in female patients with serum creatinine $>1.4 \mathrm{mg} / \mathrm{dl}$.

188 Vitamins and minerals are prescribed in study population. Vitamin B6, B9, B12 are essential in production of RBC, as the CKD patients are anaemic vitamin are very essential. Kidneys activate vitamin D, into calcitriol. Calcitriol maintain blood calcium levels and also remove extra phosphorus, to balance phosphorus and calcium levels in the blood, but in CKD the normal function is altered hence Calcium+ Vitamin D3 is given. Calcium gluconate is given to treat low calcium levels and in hyperkalaemia.

Risk of infection in CKD patients is high because of antibiotics usage. A total of 136 antibiotics were given. $\mathrm{H}_{2}$ blockers and PPIs are mostly prescribed drugs to reduce stress induced ulcers and as symptomatic therapy. A total of 114 antiulcer drugs were given study population. Constipation is complication of CKD hence laxatives are mostly preferred drugs, $12(1.03 \%)$ of laxatives are prescribed. Based on comorbidities with CKD the other drugs such as Antiplatelets 53 (4.50\%), Bronchodilators 44 (3.78\%), Lipid lowering agents 40 (3.43\%), Alkalizers 22 (1.89\%), Cardiac glycosides, Anti tubercular therapy 12 (1.03\%), Corticosteroids 11 (0.94\%), Analgesics 7 (0.60\%), Anticoagulants 5 (0.42\%), Antifungals 2 $(0.73 \%)$ and Thyroid drugs $1(0.08 \%)$ have been prescribed.

282 possible drug - drug interactions were found in prescriptions, among them 138 (48.90\%) were major drug interactions, followed by 117 (41.40\%) moderate drug interactions, and followed by 27 (9.57\%) minor interactions were found. This due to polypharmacy in many prescriptions. In Alessandra Batista Marquito, Natalia Maria da Silva Fernande study [7] majority are moderate drug interactions $76.9 \%$, followed by major drug interactions $16.8 \%$ and minor drug interactions were $5.9 \%$.

In the present study, the total number of drugs prescribed for 125 patients is 1163 drugs, the average number of drugs per prescription was 9.3 which is higher than WHO prescribing indicators (1.6 - 1.8). The percentage of drugs prescribed by generic name was $52,27 \%$ which is less than WHO prescribing indicators $(100 \%)$. The percentage of prescriptions with an injections prescribed was $95.20 \%$ which higher than WHO prescribing indicators (13.4 - 24.1\%). The percentage of prescriptions with an 
antibiotics prescribed was $67.2 \%$ which is also higher than WHO prescribing indicators. Percentage of drugs prescribed from WHO EDL 2016 was $62.94 \%$ which is also less than WHO prescribing indicators (100\%).

\section{Conclusion}

It is concluded that the prevalence of polypharmacy was very high in patients with CKD. Diuretics, anti-hypertensives, oral hypoglycaemic drugs were more frequently used in CKD patients because of high prevalence of co morbidities. Medication prescribing patterns suggest a high number of medications used in CKD patients with increased possibility of drug interactions. Continuous medical education of physicians and collaboration with clinical pharmacist is an important issue for quality improvement regarding renal impaired patients.

\section{Bibliography}

1. Shipra J., et al. "A systematic review of prescription pattern monitoring studies and their effectiveness in promoting rational use of medicines". Perspectives in Clinical Research 6.2 (2015): 86-90.

2. K/DOQI clinical practice guidelines for chronic kidney disease: evaluation, classification, and stratification.

3. Tamilselvan T., et al. "Stody Of Drug Utilisation Pattern Of Chronic Renal Failure Patients In A Tertiary Care Hospital”. International Journal of Pharmacy and Pharmaceutical Services 6.9 (2014): 482-484.

4. Elahi Elhami and Kiran Nagaraju. "Drug utilisation evaluation of antihypertensive drugs in diabetic patients with CKD". World Journal of Pharmacy and Pharmaceutical Sciences 4.11 (2015): 1159-1166.

5. Alwyn P Saju., et al. "Prescribing pattern and cost effective analysis of antihypertensive drugs in chronic kidney disease patients". European Journal of Pharmaceutical and Medical Research 3.1 (2016): 219-225s.

6. Paul A James., et al. "Evidence Based guidelines for the management of high blood pressure in adults. report from the panel members appointed to the eighth". Joint National Committee (JNC8) (2013): 284-427.

7. Alessandra Batista Marquito., et al. "Identifying potential drug interactions in chronic kidney disease patients". Jornal Brasileiro de Nefrologia 36.1 (2014): 26-30.

\section{Assets from publication with us}

- Prompt Acknowledgement after receiving the article

- Thorough Double blinded peer review

- Rapid Publication

- Issue of Publication Certificate

- High visibility of your Published work

Website: www.actascientific.com/

Submit Article: www.actascientific.com/submission.php

Email us: editor@actascientific.com

Contact us: +919182824667 